\title{
The Unbearable Whiteness of the Polish Plumber and the Hungarian Peacock Dance around "Race"
}

\author{
József Böröcz and Mahua Sarkar
}

Whiteness is inherently unstable, heterogeneous, and impure. ${ }^{1}$ So is "eastern Europe."2 Making matters worse, the moral-geopolitical construct of a hyperreal "Europe," rampant in post-WWII western Europe, has come to connote a claim to two global monopolies. ${ }^{3}$ One is an increasingly exclusive entitlement to "racial whiteness." 4 Another, a claim of unique, essential "goodness." 5 The reverse-synecdochic practice of labeling (putatively both white and benign) western Europe as "Europe" serves to conceal the many falsehoods, contradictions, and conflicts that inhere in that monopoly claim.

Given all that, May 1, 2004-the date of the diffident but resolute "accession" of eight erstwhile-state-socialist "east European" states to the European Union-definitely spelled trouble. ${ }^{6}$ Thirteen of the fifteen established member states of the EU announced that access to their labor markets for citizens of the new member states would be delayed by seven years after "accession," signaling some of the complications that lay ahead. ${ }^{7}$ The economic grounds

1. See Joseph Pugliese, "Race as Category Crisis: Whiteness and the Topical Assignation of Race." Social Semiotics 12, no. 2 (August 2002): 149-168, Iga Mergler, "White Or Not White? The Racial Representations of the Poles in the British Media after 2004" (PhD Diss., Central European University, Budapest, 2004); Chris Ruiz-Velasco, "Order Out of Chaos: Whiteness, White Supremacy, and Thomas Dixon, Jr.” College Literature 34, no. 4 (Fall 2007): 151; Patricia de Santana Pinho, "White but Not Quite: Tones and Overtones of Whiteness in Brazil," Small Axe 29, no. 2 (July 2009): 44, Pugliese, "Race as Category Crisis"; Helen Moore, "Shades of Whiteness? English Villagers, Eastern European Migrants and the Intersection of Race and Class in Rural England," Critical Race and Whiteness Studies 9, no. 1 (2013) at http://acrawsa.org.au/files/ejournalfiles/191Moore20131.pdf (last accessed February 20, 2017).

2. Larry Wolff, Inventing Eastern Europe: The Map of Civilization on the Mind of the Enlightenment (Stanford, 1994); Anita Starosta, Form and Instability: Eastern Europe, Literature, Postimperial Difference (Evanston, IL, 2016).

3. Dipesh Chakrabarty, Provincializing Europe: Postcolonial Thought and Historical Difference, (Princeton, N.J, 2000), 66.

4. Alastair Bonnett, "Who Was White? The Disappearance of Non-European White Identities and the Formation of European Racial Whiteness," Ethnic and Racial Studies 21, no. 6 (November 1998): 1029-55.

5. József Böröcz, "Goodness Is Elsewhere: The Rule of European Difference.” Comparative Studies in Society and History 48, no. 1 (January 2006): 110-38.

6. József Böröcz "East European Entrants to EU: Diffidently Yours.” The Polish Foreign Affairs Digest 3, no. 4(9), (2003): 47-58.

7. Britain and Ireland were the only west European EU-member states that did not delay access to their labor markets to citizens of the new member states. See József Böröcz and Mahua Sarkar, “What Is the EU?” International Sociology 20, no. 2 (June 2005): 153-73, Dóra Husz and Dorothee Bohle, "Whose Europe Is It? Interest Group Action in Accession Negotiations: The Cases of Competition Policy and Labor Migration,” Politique européenne 1, No. 15 (2005): 85-112; Thomas Plümper and Christina J. Schneider, "Discriminatory European Union Membership and the Redistribution of Enlargement Gains," Journal of Conflict Resolution 51, no. 4 (August 2007): 568-87; József Böröcz, “The Collapse of State Socialism in the Soviet Bloc and Global Labor Migration" in Mary Rowlinson, Wim Vande- 
for such temporary restrictions on labor inflows are widely known to be shaky at best: there is near-consensus in the scholarly literature that " $[t]$ he highest [national economic] gains from post-accession [movement of east European labor] were achieved by the United Kingdom and Ireland, which opened their labor markets for mobile workers from [the new member states] already in $2004 .^{8}$ That of course has practically no bearing on west "European public opinion"-a body whose members are, for the most part, supportive of "their" governments' delaying tactics. ${ }^{9}$

Meanwhile, the removal of the recently-attained formal sovereignties of the former-state-socialist-"bloc" societies-a generic requirement for membership in the "sharing and pooling" of sovereignties that the EU representsbegan a good ten to fifteen years earlier, in the early nineties, at the point where their freshly post-state-socialist political elites made a commitment to pursuing full membership in the European Union. ${ }^{10}$ Given the powerful emotive significance of having been "robbed" of sovereignty by the Sovietcentered geopolitical project, the "handing-over" of formal sovereignties to the EU was bound to be a political minefield. The current success of the nationalist Right in east-central Europe can be seen as a consequence-at least in part-of the widespread critique, if not demonization, of the liberal governments that managed the accession process.

It is in this context, seven months after "accession" and almost six and a half years before the expiry of the "transitional arrangements" barring east European labor from the right to employment in the earlier fifteen member states of the European Union, that the French magazine Charlie Hébdo published a satirical article by Philippe Val. ${ }^{11}$ The article proposed the ostensibly hilarious and bizarre idea that "a Polish plumber or an Estonian architect could move to other [member states of the EU] to offer their services" at prices that would presumably undercut local markets. ${ }^{12}$ Indeed, as Philippe

kerchkove, Ronald M. S. Commers, and Tim Johnston, eds., Labor and Global Justice: Essays on the Ethics of Labor Practices under Globalization (New York, 2014), 85-104.

8. Agnieszka Fihel, Anna Janicka, Paweł Kaczmarczyk and Joanna Nestorowicz, Free Movement of Workers and Transitional Arrangements: Lessons from the 2004 and 2007 Enlargements (Warsaw, 2015) at https://www.researchgate.net/publication/277475204 Free_movement_of_workers_and_transitional_arrangements_lessons_from_the_2004_ and_2007_enlargements (last accessed March 5, 2017).

9. See, e.g., Natalie Schimmel, "Welcome to Europe, But Please Stay Out: Freedom of Movement and the May 2004 Expansion of the European Union,” Berkeley Journal of International Law 24, no. 3 (2006): 760-800, at http://scholarship.law.berkeley.edu/bjil/ vol24/iss3/1 (last accessed February 20, 2017).

10. See, e.g., Böröcz and Sarkar, “What Is the EU?”; Wade Jacoby, The Enlargement of the European Union and NATO: Ordering from the Menu in Central Europe (Cambridge, UK, 2004).

11. Val is a noted journalist and a singer who joined, a few weeks after the brutal attack on the editorial offices of Charlie Hébdo, the extreme-right organization Front National. See "Philippe Val, ex-Charlie Hebdo, Rejoint l'Aile Droite du Front National," Égalité \& Réconciliation, November 17, 2015, at www.egaliteetreconciliation.fr/PhilippeVal-ex-Charlie-Hebdo-rejoint-l-aile-droite-du-Front-national-36176.html (last accessed February 20, 2017).

12. Matteo Gnes, "European Legal Integration? New Possibilities for EU and NonEU Citizens?" in Lucica Matei, ed., Normativity, Fundamental Rights, and Legal Order in 
de Villiers, a spokesman for and unsuccessful presidential candidate of the French xenophobic right put it in a subsequent interview in Le Figaro, the fear was that they would do so "at the salary and rules of social protections of [their countries] of origin." ${ }^{13}$ De Villiers did not bother to explain why he thought east European businesses would not adjust their prices and salaries upward, to approximate those prevailing in the French market. Nor did anyone seem to pose that question to him.

A relatively jovial public give-and-take followed, including an intervention by former EU Commissioner Frits Bolkenstein, who committed the fauxpas of openly contemplating the possibility that even he might hire a Polish plumber to do some work in his house in northern France, given the difficulties of finding a good professional locally. ${ }^{14}$ Bolkenstein seemed to be making an abstract, properly EU-"liberal" point by highlighting a set of possibilities that nonetheless appeared to have been largely hypothetical at the time. ${ }^{15}$ The subsequent referendum, held on May 29, 2005, on the European Union's Constitutional Treaty that proposed de-nationalization of hitherto memberstate-level authority to regulate services, was defeated in France as it was seen a threat to the "French (and 'European') social model."16 It was likewise defeated in the Netherlands three days later. ${ }^{17}$ It would seem that the trope of the Polish Plumber played quite a historic role in holding back the post"nation-state" transformation of western Europe. ${ }^{18}$

It would be easy to claim that, in the French debates, the Polish Plumber served as a "symbol of wild liberalization and of the invasion of hungry and underpaid workers, willing to work at any hour of day and night in order to earn a few Euro." 19 However, is that reading-condescending and disparaging as it is of "Poles" (indeed, by extension, of "east Europeans") along class, gender and ethnic lines-exhaustive of the culture-productive capacity of this trope?

The response of the Polish government that followed the French discussions would seem to suggest otherwise. We focus here on the two versions

the EU / Normativité, droits fundamentaux et ordre juridique dans l'UE, "The Dialogues of EPLO at NSPSPA" Series, No.1/2010 (Bucharest, 2010) at http://aei.pitt.edu/14411/1/ Normativity\%5B1\%5D_Lucica_Matei.pdf (last accessed February 20, 2017), 52.

13. “. . . la directive Bolkestein permet à un plombier polonais ou à un architecte estonien de proposer ses services en France, au salaire et avec les règles de protection sociale de leur pays d'origine." See Philippe de Villiers, Interview, March 15, 2005, in "Villiers: "La grande triche du oui," Le Figaro, March 15, 2005. For an English version, see Claudia Sternberg, "What Were the French Telling Us by Voting Down the 'EU Constitution'? A case for interpretive research on referendum research," Comparative European Politics (October 2015): 14.

14. Gnes, "European Legal Integration?," 53.

15. Sternberg, "What were the French," 2.

16. Gnes, "European Legal Integration?," 53.

17. There are serious issues with the scope of validity of the terminology of "the European social model”-see József Böröcz, "Global Inequality in Redistribution: For A WorldHistorical Sociology of (Not) Caring," Intersections-East European Journal of Sociology and Politics 2, no. 2 (2016): 57-83.

18. I will capitalize the Polish Plumber as a referent to a trope.

19. Gnes, “European Legal Integration?... ” p. 53. 


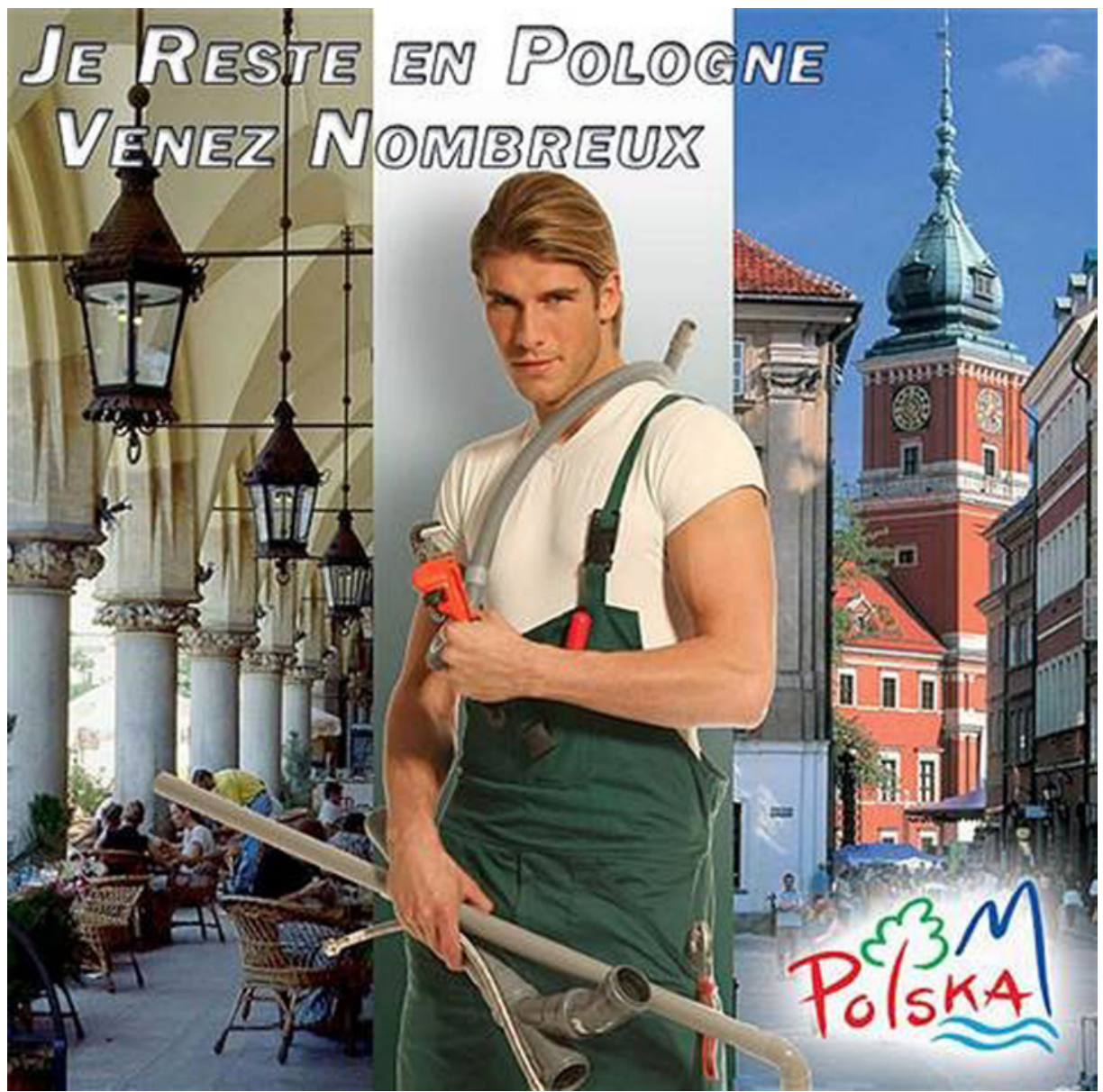

Figure 1. "I'm Staying in Poland. Come in Large Numbers." Travel advertisement, produced, and reproduced here by permission, by the Polish Office for Tourism. Source: http://media3.s-nbcnews.com/j/msnbc/Components/ Photos/050629/050629_polish_hmed_330a.grid-6×2.jpg (last accessed February 3, 2017).

of a poster that the National Tourist Office of Poland published in this context. ${ }^{20}$ Both depicted a handsome, blond male model posing with plumbing equipment in front of some of Poland's iconic tourist sites. One read "Welcome to Poland." 21 The other announced, "I'm staying in Poland-come in large numbers!"22 (See Figure 1 above.) Having "reversed," so to speak, the thrust of the French anxiety over the "invasion" of Polish working class men, the

20. See “Un Bon Tuyau de l'Office du Turisme Polonais," Vanksen, June 16, 2005, at http://www.vanksen.fr/blog/un-bon-tuyau-de-loffice-du-tourisme-polonais/ (last accessed February 20, 2017).

21. https://c2.staticflickr.com/4/3177/2595175298_611c1c397c.jpg (last accessed March 2, 2017).

22. https://upload.wikimedia.org/wikipedia/en/c/cc/Polish_Plumber.jpg (last accessed March 2, 2017). 
poster thus acquired a life of its own on social media, and seemed to diffuse, with humor, the tension that inhered in the French discussion. Soon, the matter seemed to subside into a more general discussion about nationalist versus liberal conceptions of statehood and the place of France in the European Union.

But let us take a closer look at the terms in which this "turning around" of the discourse was affected. How might we read what the figure of the Polish plumber evinces in these posters? One striking feature is of course his unmistakable blondness, eerily reminiscent of the "Aryan" male figures in the propaganda pamphlets from 1930s Germany. Read in this context, the message of the second poster-"come in large numbers"-is similarly disturbing, harkening back, perhaps unwittingly, to a very different European "union" (the appropriately color-coded Plan Weiß-the Nazi German military code name of the invasion of Poland) not so long ago.

Perhaps the more obvious message that the Polish Government intended to highlight through these posters was the allure of working class Polish maleness-robust, self-confident and brawny, reminiscent even of the title of Andrzej Wajda's Man of Iron, but now clean, blond, and most importantly, inviting. Seen from this vantage point, the poster's message-“come in large numbers"-is suggestive of yet another kind of possible union; the strategic placement of multiple phallic objects on the posters' visualscape underscoring the sexual innuendos inherent in the message. And through this sexualization of the working-class male subject, expression of ethnonational pride ("I'm staying here"), and the "Nordic" self-representation of Polish maleness, we get a glimpse of the reactive formation of a particular kind of east European subjecthood: inviting, ready for consumption, west-compatible, and "White."

Needless to say, the matter did not end there and, in due course, the allegorical figure of the Polish Plumber crossed the English Channel. During the entire period from the formal "accession" of the eight erstwhile-state-socialist states to the EU on May 1, 2004 (and the birth of the Polish Plumber in Paris later in the same year) to the "Brexit" vote of June 23, 2016, the increasingly demonized figure of the east-European-worker dominated discursive space about labor policy, social rights, and eventually, European Union membership. All that culminated in the "Brexit" decision, causing the collapse of the Tory government, possibly foreshadowing Scotland's secession from the UK, and unleashing a crisis of governance both in London and Brussels. The tone of the British conversation was considerably more ferocious than the French..$^{23}$ The frequency of acts of physical violence against Poles increased dramatically. ${ }^{24}$

23. See Zack Beauchamps, “Brexit Isn’t about Economics. It is about Xenophobia,” Vox, last modified June 24, 2016, at www.vox.com/2016/6/23/12005814/brexit-eu-referendumimmigrants (last accessed February 21), especially the example of anti-Polish graffiti.

24. Between 2004 and 2014, there had been an estimated "tenfold rise in attacks" against Poles in Great Britain, see Johnny McDevitt, "New Figures Reveal Dramatic Increase in Hate Crimes against Polish People," The Guardian, June 11, 2014, at www. theguardian.com/society/2014/jun/11/polish-people-rise-in-attacks-blame-recessionpoliticians-media (last accessed February 21, 2017). On August 29, 2016, a Polish man was killed in Harlow, Essex. News reports suggest it may have happened because he spoke Polish in public. See Ben Quinn, "Six Teenage Boys Arrested over Death of Polish Man in 
A single-cause political party was built on anti-east-European-"immigrant" rhetoric, and significant portions of otherwise non-extreme-right-identified voters were persuaded by it enough to sacrifice their unrestricted access to the large space of the European Union for the dubious comfort of seeing the "Polish Plumber deported."25

The presence of European labor in the British labor market since 2004again, the UK was one of the two EU-member states that did not delay opening its labor market to citizens of the new member states-has unleashed multidimensional processes of racialization. As Jon Fox, Laura Moroşanu, and Eszter Szilassy argue very usefully, racialization is "the socially constructed contingent outcome of processes and practices of exclusion" wherein "the category of 'race' is invoked and evoked in discursive and institutional practices to interpret, order, and indeed structure social relations." ${ }^{26}$ To be clear, as Fox, Moroşanu, and Szilassy point out further, "the nominal absence of somatic difference does not get in the way of xenophobic racism; it turns out racialized difference can be invented in situ." 27 The Polish poster featuring a "Nordic" Polish Plumber can only go so far in "fixing" the "race" doubts about east Europeans in the British context. If anything, as the analysis here suggests, it may well have been wishful, even audacious, thinking.

At the heart of the issue lies, of course, the question of the "content" of whiteness in contemporary western Europe. Previous work on the historical dynamics of whiteness has shown that its borders are semi-permeable for groups construed as "just outside" of it. Based mainly on stylized representations of collective "single-ethnicity" stories in the United States, a considerable literature has sprouted around the notion of "becoming White." 28 However, the migration within the European context is somewhat different from the history of European immigration to the US: for, in the EU, both the "destination" and the migrant-emitting societies share membership in the same public authority, which provides them at least nominally equal rights to travel, work, study, relocate to, and live anywhere within that shared space.

As a matter of fact, questions can be raised about the very applicability of even the term "(im)migrants" and "(im)migration" with respect to Europeans moving within the EU. This is not a pedantic, scholarly quibble: at a press conference held jointly with then British Prime Minister David Cameron in

Essex,” The Guardian, August 30, 2016 at www.theguardian.com/uk-news/2016/aug/30/ five-teenage-boys-arrested-after-man-dies-following-attack-in-essex (last accessed February 21,2017$)$.

25. Nick Robinson, “UKIP: Should the Polish Plumber Be Deported?” BBC News, November 19, 2014, at www.bbc.com/news/uk-politics-30118855 (last accessed February 21, 2017).

26. Jon Fox, Laura Moroşanu and Eszter Szilassy, "The Racialization of the New European Migration to the UK,” Sociology 46, no. 4 (August 2012): 681-82.

27. Ibid., 682.

28. See Karen Brodkin, How Jews Became White Folks and What That Says about Race in America (New Brunswick, NJ, 1998); James R. Barrett and David Roediger, "How White People became White," in Paula Rothenberg, ed., White Privilege: Essential Readings on the Other Side of Racism (New York, 2002), 29-34; Noel Ignatiev, How the Irish became White, (New York, 2009); Jennifer Guglielmo and Salvatore Salerno, Are Italians White? How Race is Made in America (New York, 2003). 
Budapest in January 2016, Prime Minister of Hungary Viktor Orbán repudiated a journalist who referred to Hungarians working and living in the UK as "migrants": "For us, it is very important that we are not considered as migrants. ${ }^{29}$ Words matter here. We would like to make it quite clear that we are not migrants into [sic] the U.K. We are the citizens of a state that belongs to the European Union who can take jobs anywhere freely within the European Union." 30

As in the Polish Plumber discussion in France and (even more so) in the UK, there seems to be a palpable element of "racial" downgrading inherent in the label "migrant," and the Prime Minister seems keen to extricate the ethnonational category he represents ("Hungarians") from that discounted, racialized location that it has been assigned in at least some influential west European discussions of EU policy on the ostensibly "free movement of persons." The need for such distancing seems to be even more urgent today in the post-refugee-crisis context in Hungary, where the word "migráns" ("migrant”) has acquired particularly negative overtones. ${ }^{31}$

In the early spring of 2015-when the news of the imminent arrival of large groups of people displaced by the west Asian wars reached Europe-the governments of eastern Europe were deeply mired in a complex set of asymmetrical relations with their west European partners and the EU as a whole. A pervasive sense of economic, political, and cultural dependency (including direct economic dependence on worker remittances from the western EU, not to mention an almost total dependence on the EU for infrastructural development funds) was already a fact-but perhaps most challenging was the widely felt, implicit lack of acceptance as equals in all matters European. In this sense, Poland is only one-albeit, in terms of its population, the largest-of the racialized and degraded east European entrants to the EU-sphere. Partly due to linguistic reasons, partly because of the UK government's early decision not to qualify their access to the British economy, a large part of east European labor has been in the UK for several years-the country where the racialization of east European foreign labor has taken most explicit forms recently.

It seems, therefore, that there is something to be gained in trying to situate the widely noted and deplored negative positioning of the government of Hungary with respect to the refugee influx within the racialized context

29. Notice the use of the first person plural to citizens of Hungary who live and work in the United Kingdom, quite a powerful claim of ethnonational unity, intended for the Hungarian media consumer. The legal argument is of course also unassailable. The "trick" is in switching from a commonplace, everyday conversation to a rather technical legal point.

30. Paul Dallison, “Orbán to Cameron: 'We Are Not Parasites’ British Prime Minister Seeks Hungarian Support for Migrant Benefits Curbs,” Politico, January 7, 2016 at www.politico.eu/article/orban-cameron-not-parasites-hungary-united-kingdom-brexitmigration-refugee/ (last accessed February 21, 2017).

31. "Nekünk nagyon fontos, hogy ne tekintsenek bennünket migránsoknak." Text of Orbán’s reply, as reported in the Hungarian media. See "Orbán szerint a magyarok nem migránsok Angliában,” Origo, January 7, 2016, at www.origo.hu/itthon/ percrolpercre/20160107-david-cameron-orban-viktor-budapest-sajtotajekoztato.html (last accessed February 21, 2017). 
outlined above. For the arrival of relatively large numbers of displaced people seems to have provided an excellent opportunity to the governments of eastern Europe to stake out their claim, once and for all, to essential, unquestionable whiteness. The expectation seems to be that the discursive denigration of the "Arab," "Muslim" "migrants" (as well as the institutional indifference to their suffering) would somehow shore up the essential whiteness and Christian-ness of Hungarians (east Europeans). Certainly, Hungarian Prime Minister Viktor Orbán's performance-his own "peacock dance"-as a panEuropean white supremacist appears, in this context, as a strategy devised to enhance his and his government's "whiteness" credentials. ${ }^{32}$ It is possible that this reading explains in part the overwhelming support Orbán's anti-refugee, anti-human-rights policy seems to enjoy among the Hungarian public.

Being treated with ambiguity, being kept in liminal, borderline status, and being constantly questioned, let alone accused of lacking certain essential "European" cultural qualities along "racial" lines is of course a shared experience for a great majority of humankind. Whiteness is a key instrument for the propagation of that cognitive schema. What is somewhat unique about the position of eastern Europe in the world today is that, as citizens of EU-member states, many inhabitants of the region perceive the European Union, rightly or wrongly, as a resource that offers them an opportunity to boost their "racial" credentials, that is, a chance to proceed "upward" on the scale of privilege in an obviously unequal, oppressive and discriminatory system. Hence, they cheer and applaud their Prime Minister's "peacock dance" around "race," without considering the genocidal "downside" of their positioning. The alternative-taking an anti-racist, system-critical position regarding the worldappears to be unthinkable in a post-state-socialist context, exorcised of the supposed evil of progressive, Left politics.

32. Sometime in early June 2012, Orbán made a set of disparaging remarks about the deep dishonesty of European politics as a fanciful, implicit bargaining process. He referred to the whole process as "pávatánc"-i.e., a "peacock dance." See Tóth Âkos "Pávatánc," Népszabadaság Online, June 4, 2012, at http://nol.hu/velemeny/20120604pavatanc-1312137 (last accessed February 21, 2017). 